\title{
EVOLUTION OF EMPLOYMENT-UNEMPLOYMENT IN CONCEPTUAL AND THEORETICAL FRAMEWORK IN THE ECONOMIC THOUGHT HISTORY
}

\author{
Ahmet DENIZ*, Ferhat DALBOY ** \\ * Kafkas Üniversitesi, **Kafkas Üniversitesi \\ E-mail: ahmetdenizz@hotmail.com*,ferhat_36_dalboy@hotmail.com** \\ Received : 17 February 2015; Revised : 29 March 2015; Published : 01 May 2015 \\ Copyright (C) 2015 Ahmet DENIZ ve Ferhat DALBOY. This is an open access article \\ distributed under the Eurasian Academy of Sciences License, which permits unrestricted use, \\ distribution, and reproduction in any medium, provided the original work is properly cited.
}

\begin{abstract}
The facts that the value given to labor is small in labor market, with the motive of more profit employers to perceive everything that costs more important than human, and employees becoming forced to work in jobs they do not want and under conditions they do not want, lead us to prepare this study. In order for the study to be understood better, the research has been tried to be placed in a conceptual and theoretical frame about employment and unemployment. By analyzing its evolution in Economic Thought History; it is believed to be important in terms of guiding other researchers on topics of Labor Force, Employment and Unemployment, and what was experienced in economic life about these topics. In our study, basic concepts of employment and unemployment were underlined and introductory information was given.
\end{abstract}

Keywords: Employment, Labor Force, Unemployment, Economy.

\section{İstihdam-İşsizliğin Kavramsal ve Teorik Çerçevede İktisadi Düşünce Tarihindeki Evrimi}

\section{ÖZET}

İş gücü piyasasında emeğe verilen değerin az oluşu, işverenlerin daha fazla kar güdüsüyle maliyet oluşturacak diğer her şeyi insandan daha önemli görmeye başlaması ve çalışanların istemedikleri işlerde istemedikleri koşullar altında çalışmaya mecbur hale gelmeleri bizi bu çalışmayı hazırlama hususunda yönlendirmiştir. Konunun daha iyi anlaşılabilmesi için araştırmanın istihdam ve işsizlik ile ilgili kavramsal ve teorik bir çerçeve oluşturulmaya çalışılmıştır. İktisadi Düşünce Tarihinde geçirmiş olduğu evrimler analiz edilerek; İş gücü, İstihdam ve İşsizlik, konularında iktisadi hayata yaşananları diğer araştırmacılara yol tutması açısından önemli olacağı düşünülmektedir. Çalışmamızda istihdam ve işsizliğin temel kavramları üzerinde durularak tanıtıcı bilgiler verilmiştir.

Anahtar Kelimeler: İstihdam, İş Gücü, İşsizlik, Ekonomi. 


\section{Giriş}

İşsizlik olgusu bünyesinde bireysel ve toplumsal sorunları beraber barındırmaktadır. Sorunun bu kadar önemli boyuta ulaşmasının temelinde, zaten kendi başına önemli bir sorun teşkil eden işsizliğin beraberinde getirdiği ekonomik ve sosyal sıkıntıların toplumsal yaşamda yol açtığı problemler yer almaktadır. İşsizlik görülen toplumun genel yapısı itibariyle yaşanan sorunlara yönelik daha olumsuz algılar mevcuttur. Gelişmiş ülke ekonomilerinde görülen işsizlik kısa süreli ve telafisi mümkün olabilecek sonuçlar doğururken; gelişmemiş ülkelerde görülen işsizliğin yaratacağı sorunlar ise daha uzun sürede daha derin etkiler oluşturmakta ve bu etkilerin telafisi daha zor olmaktadır. Başlı başına iktisadi bir sorun olarak gözlenen işsizliğin, gelişmiş ve gelişmekte olan ülkelerde ortaya çıkma nedeni farklılık göstermektedir. Gelişmiş ülkelerde yeterli talebin oluşturulamamasından kaynaklanan işsizlik; gelişmemiş ülkelerde tasarrufların istenilen seviyeye ulaşamaması ve hızlı nüfus artışı gibi nedenlerden dolayı istenilmeyen bir durum olarak baş göstermektedir.

İşsizlik olgusu uzun yıllarca boyunca bireyin kendisinden kaynaklanan bir durum olarak görülmüştür. Fakat yıllardan beri yapılan çalışmalar göstermektedir ki işsiz kalmak bireylerin sadece kendi iradeleri ile karar verebileceği bir durum değildir. Bu çalışmaların 1şı̆̆ında işsizliğin bireyin problemi olmaktan sıyrılıp toplumun hatta küreselleşmenin de meydana getirdiği küresel etki ile dünyanın en büyük ekonomik sorunlarından biri haline geldiğini söylemek mümkündür.

\section{2. İşsizlik Türlerine Genel Bakış}

Gelişmiş, gelişmekte olan ve geri kalmış ülke ekonomilerinin en temel ortak sorunu olan işsizlik kavramı;

- Cari ücretlerden ve mevcut çalışma koşullarından dolayı kendi istekleriyle istihdama dâhil olmak istemeyenlerin,

- $\quad$ Ücretlere ve koşullara razı olup da iş bulamayanların,

- $\quad$ İş değişikliği nedeniyle arada kaybedilen zamandan dolayı işsiz sayılanların,

- $\quad$ Ekonominin iç dinamiklerinden dolayı dönemsel olarak işsiz kalanların,

- Mevsimsel durgunluklar nedeni ile yılın belli bir zaman dilimini çalışmadan geçirenlerin,

- $\quad$ Üretimde sermaye yoğun girdilerin tercih edilmesiyle emeğe duyulan gereksinimin azalması sonucu işsiz kalanların,

- C Çalışıyor olsa bile toplam üretimde pay sahibi olduğu belli olmayanların yani marjinal verimliliği sıfır olanların, iş gücüne dahil olamaması neticesinde kendi içerisinde türlere ayrılabilmektedir.

\section{1. İradi-Gayri İradi İşsizlik Türü}

Cari ücret düzeyinde ve mevcut çalışma koşullarında çalışmak istemeyenlerin meydana getirdiği işsizlik türüne iradi işsizlik denir. Bu tür işsizlere ekonomide verilecek iş vardır. Ancak daha yüksek ücret ve daha iyi çalışma koşulları istekleri neticesinde kendi istek ve iradeleri ile işsiz kaldıklarından dolayı bu tür işsizler gönüllü işsiz (Pekin, 1996: s.115) olarak nitelendirilmektedirler.

Açık işsizlik ya da gönülsüz işsizlik adı verilen bir diğer işsizlik türü de gayri iradi işsizliktir. Gayri iradi işsizlik, cari ücret düzeyinde çalışmaya razı olan fakat istihdam edilmemiş olan 
insanların karşılaştıkları işsizlik türüdür. Gayri iradi işsizlik kavramı zaman zaman gerçek işsizlik kavramı olarak da kullanılmaktadır (Ardıç, 2004: s. 178).

Görüldügü üzere iradi-gayri iradi işsiz ayrımını yapabilmek işgücü piyasasının ve işgücünün heterojen olması bakımından kolay değildir. Bu durumu tıp eğitimi almış bir doktorun, çöpçü olarak çalışmak istememesi şeklinde değerlendirirsek, doktorun tıp görevlisi olarak iş bulamaması gayri iradi işsizlik gibi görülmektedir. Fakat düşük reel ücret düzeyinde çalışmama arzusundan kaynaklanan işsizlik ise iradi işsizlik örneği olarak karşımıza çıkmaktadır (Oktay, 1998: s.197).

\subsection{Konjonktürel İşsizlik Türü}

Gayri iradi olarak görülen bu işsizlik türü iktisadi yaşamın farklı seviyelerde faaliyet gösterememesi neticesinde ekonomide dalgalanmalar oluşmasından dolayı ortaya çıkarak konjonktürel işsizlik adını almaktadır. Dönemsel dalgalanmalarının azaldığı evrelerde, yani ekonomide durgunluğun gözlendiği zamanlarda çalışanlar işlerini kaybetmektedir. Dalgalanmaların arttığı dönemlerde ise işsizliğin daha az olması veya işsizlik sorununun gözlenmemesi mümkündür. Konjonktürel işsizliğe talep yetersizliği neden olmaktadır. İşsizlik talep yetersizliği görülen dönemlerde artmakta, genel talep düzeyinin arttı̆̆ı dönemlerde ise azalış göstermektedir (Boztepe, 2007: s.16).

\subsection{Mevsimsel İşsizlik Türü}

Mevsimsel işsizlik, mevsim şartlarına bağlı olarak çalışan işgücünün yaşadığı işsizlik türüdür. Bazı işler yapıları gereği sadece mevsimsel olanakların izin verdiği ölçüde yapılabilmektedir. Mevsimsel işsizlikte kanunlar engellenen işler de doğal şartlarla beraber işsizlik üzerinde etkili olmaktadır. Örneğin balıkçıların yasal olarak sadece belirli periyotlarda avlanmaları, avlanmanın yasaklandığı bazı dönemlerde bu sektörde çalışanların işlerini dönemsel olarak kaybetmelerine neden olmaktadır. Tarımsal sanayilerde çalışanların ise mevsim sonunda sadece geçici işçi olarak çalışabilecekleri aşikârdır (Kurt, 2005: s.18).

\subsection{Gizli İşsizlik Türü}

Ekonomide çalışır görüldüğü halde toplam üretime katkısı bulunmayanların oluşturduğu işsizlik türüne gizli işsizlik denilmektedir. Verimliliğin ve emek başına ödenen ücret miktarının düşük olduğu ekonomilerde bu tür işsizliğin görülme sebebi bir yerine iki ya da daha fazla kişiye iş verilmesidir. Az gelişmiş ülkelerde özellikle tarım kesiminde küçük aile işletmelerinin egemenliği söz konusudur. Bu işletmelerde aile fertlerinin hepsi iş sahibi gibi görünmektedir. Fakat bunların bir kısmının çalışmayı terk etmesi veya çalışma hayatına yeni bireylerin katılması toplam üretimde ne bir artış ne de bir azalış oluşturmayacağından bu kişilerin üretim düzeyine katkısının olmadığı görülecektir (Ülgen, 2004, s.250).

\subsection{Teknolojik İşsizlik Türü}

Bir ekonomide bazı üretim dalları uzun zamandır emek yoğun teknoloji ile faaliyetlerini sürdürürken, faktör fiyatlarındaki değişmeler nedeniyle sermaye yoğun teknoloji seçilebilir. İşgücü yerine sermaye malları ikame edilebilmesiyle bir kısım işgücü işsiz kalır. Bu sebeple kullanılan teknolojideki değişme ve gelişmeye bağlı olarak ortaya çıkmış olan işsizlik türüne teknolojik işsizlik denilmektedir (Şahin, 1997, s.170). 


\subsection{Doğal (NAIRU) İşsizlik Türü}

İşçilerin bazen çalışma koşullarını veya kazandıkları ücreti beğenmeyerek iş değiştirmek istemektedir. Daha iyi çalışma koşulları elde edebilmek için iş değiştirme kararı veren işçilerin bu değişiklik arasında neden olduğu işsizlik türü firiksiyonel işsizlik olarak tanımlanmaktadır (Türkbal, 2005, s.350). Zaman içinde üretim teknolojisinde ve tüketici tercihlerinde meydana gelen değişmelerin neden olduğu ekonominin talep ve üretim yapısındaki değişikliklere, işgücünün uyum sağlama sürecinin yol açtığı işsizliğe ise yapısal işsizlik denilmektedir. Tarım sektöründe makineleşmeye geçilmesi ve sanayi sektöründe otomasyon üretiminin tercih edilmesi bu işsizlik türünün ortaya çıkmasına neden olurken zevk ve tercihlerde gözlenen moda eğiliminin geleneksel ürünlerin üretiminde uzmanlaşan bireylerin, bu alanda üretim yapmayı durdurması da yapısal işsizlik doğurucu bir nedendir (Ünlüönen ve Tayfun, 2007: s.205).

Friksiyonel ve yapısal işsizliğin toplamı şeklinde ifade edilebilecek bir tanım verilebilinir. Doğal işsizlik kavramı, devresel nedenler ile işini kaybedenler dâhil edilmemek üzere, var olan işten memnun olmayarak yeni iş arayışına girenleri, çalışma yeri, gelir gibi sebeplerle işi beğenmeyip işsiz kalanları, mevsimsel nedenlerle işini kaybedenleri ifade eder. Ayrıca yaşlılık, cinsiyet, engelli veya eskiden hüküm giyme sebebiyle iş bulması zor olanları da kapsamı dahline almaktadır. Ekonominin dengede olduğu yanda ve durağan bir halde seyrettiği durumlarda bile varlığı muhtemel olan doğal işsizlik, gelişen sosyal güvenlik uygulamaları ile birlikte artış göstermektedir. Doğal işsizlik oranı ayrıca, enflasyonist bir etki oluşturmayan işsizlik oranı olarak da ifade edilip parasalcı iktisatçılar tarafından enflasyonu tetiklemeden gerçekleşen işsizlik oranı şeklinde de tanımlanmaktadır (Noyan, 2012: s.122).

\section{3. İşsizliğin Nedenleri Ve Sonuçları}

AB’ye üye ülkeler de dâhil olmak üzere bugün bütün ülkelerin karşı karşıya olduğu en önemli sorunlardan birisi işsizliktir. Tüm dünyada yeteri kadar yeni ve geliri yüksek iş yaratmak mümkün değildir. Bir ülkede işsizlikten olumsuz etkilenen sadece üretim ve ekonomik kalkınma değildir. İşsizlik aynı zamanda, bir takım sosyal problemler de doğurmaktadır. Görülmektedir ki işsizlik, işsiz kalan bireyin kendi problemi olmaktan çıkıp ekonomi, işverenler ve devlet üzerinde de sorun yaratıcı bir etki, olumsuz birtakım sonuçlar doğurmakta istenmeyen ve telafisi güç neticelere neden olmaktadır (Türkcan, 2007: s.18).

Var olan iş gücünün verimli kullanılması bir toplumun en büyük zenginlik kaynağını oluşturmaktadır. $\mathrm{Bu}$ zenginliğin gerektiği gibi kullanılmaması çeşitli memnuniyetsizliklere yol açacaktır. İşsizliğin ekonomik ve sosyal sonuçları, bireysel bakımdan kazanç kaybı, refah artışından yararlanamama, ümitsizlik, gelecekten kötü beklenti, zor şartlarda yaşama olarak ortaya çıkarken; toplumsal problemler de bu unsurlar neticesinde ortaya çıkmaktadır. İş olanaklarının olmayışı veya istihdam düzeyinin yeterli seviyeye çıkarılamaması milli ekonomi üzerinde olumsuz etki yaratarak işsizlik, yoksulluk, sosyal dişlanma ve sosyal hayatta çarpık yapılaşmayı da beraberinde getirmektedir (Tatar, 2006: s.12).

\section{1. İşsizliğin Kişisel Nedenleri ve Sonuçları}

Her insanın işsizliğe yönelik psikolojik algısı işsiz geçen süre ölçüsünde farklılık göstermekte ve bu durum farklı insanlarda farklı etkilerin oluşmasını olağan kılmaktadır. İşini henüz kaybetmiş birisi için başlangıç aşaması önemsiz görülebilir. Maddi sıkıntıların başlaması umut kaybı ile birleşerek, bir işsizin psikolojik açıdan bunalımına sebep olur. Umutların 
giderek yitirildiği bu nokta işsiz kişinin moralinin ve psikolojisinin zarar gördüğü nokta olarak görülmelidir. Çünkü umut kaybı tam da bu noktada gün yüzüne çıkmaktadır. İşsiz kalan kişi becerisinin ötesinde bir iş aramanın yanı sıra başka yerlerde iş bulabileceğini düşünerek bunun ötesinde başka ülkelere göç etmeyi de göze almaktadır. Herhangi bir şekilde iş bulamayan, iş bulmak için göç edemeyen insanların özgüveni azalabilir ve kişi iş bulma ümidini kaybedebilir (Güney, 2009; s.153)

İş aramaktan vazgeçilen bu noktada kişi çaresizlik duygusu hissetmeye başlamaktadır. Bu duygunun etkisiyle geleceğe yönelik olarak atılan adımların bir fayda sağlamayacağ düşünülmekte geleceğe yönelik plan yapma güdüsünü minimize edilerek alınan kararların gelecekte olumlu sonuçlar doğurmayacağı endişesine düşülmektedir. Bütün bu olumsuz düşüncelerle birlikte işsiz kişi iş bulma şansının giderek azaldığını düşünmekte ve psikolojik çöküntünün en son noktasını yaşamaktadır. Bu dönemde kişi kendi içine kapanmayı tercih etmektedir. Eğer bu dönemde gerekli tedbirler alınmaz ise işsiz kişi hem fiziksel hem de psikolojik olarak hastalık geçirebilmektedir. Neticenin en son noktası intiharla bile sonuçlanmaktadır (Kurt, 2005: s. 33, 34).

İşini kaybeden bir çalışan aldığı ücretten ve sağladığı motivasyondan mahrum kalmaktadır. Önemli olan diğer bir husus ise insanın gelir sahibi olmasa bile yaşamını devam ettirebilmek için bazı harcamaları yapmak zorunda oluşudur. Bu harcamalar genellikle beslenme ve barınma gibi birincil ihtiyaçların karşılanması için yapılmaktadır. Emek karşılığı elde ettiği kazanç dışında başka bir geliri olmayan insanlar işsiz kalınan dönemin uzamasıyla borçlanmakta, bu borçlanma finansal bunalımları kamçılamaktadır (Yüksel, 2005: s. 261).

\section{2. İşsizliğin Topluma Dair Sonuçları}

Sürekli olarak seyreden ve yüksek oranlı işsizlik toplumda genel bir moralsizliğe ve tükenmişliğe neden olmaktadır. Uzun vadede çeşitli politikalarda işsizliğe çözüm üretilemez ise durum daha vahim hale gelir. İşsizlik oranının fazla olduğu toplumlarda siyasi ve ekonomik istikrar kaybı ve iç güvenliğin tehdit edilmesi gibi gözlenmektedir. Toplumda gerginliğin ve huzursuzluğun artmasına neden olan yüksek işsizlik, bir yandan da göç ederek gelenlere yönelik karşıtlığın oluşmasına neden olmaktadır (Güney, 2009; s.153).

Ülke halkı ve uluslararası toplu uzun süreli işsizlik gözlenen ülkelere karşı olumsuz bir bakış açısı göstermektedir. Süre gelen işsizlik gelir dağılımındaki farkın artmasına neden olarak göçe ve aile yapısında bozulmalara sebebiyet vermektedir. Günümüzde kırdan kente yönelik olarak yapılan göçler kentlerde görülen işsizliğin artmasına neden olmaktadır. Bu durum geliri düşük olan bireylerin kentlere göç etmesi ile birlikte yüksek gelirli bireyleri taklit etmeye çalışmalarına, onlar gibi yaşama arzusu oluşturmalarına neden olmaktadır. Özenilen hayatı yaşama arzusu bireylerde gelirden fazla harcama yapma durumunu oluşturmaktadır. Bunun sonucunda geç evlenmeler, aile içi huzursuzluklar, aile bütçesinde sarsıntılar gözlenmektedir (Gür ve Ural, 2004; s. 23-38)

İşsizlik aile bireyleri özellikle çocuklar açısında gelirin az oluşu sebebiyle gıda yetersizliği, düzensiz beslenme sağlık hizmetlerinden gerektiği gibi yararlanamama, aile bireylerine ve kadına yönelik şiddetin artması gibi olumsuz sonuçlar doğurmaktadır. Belirli bir eğitim alıp işgücü piyasasına dâhil olmayı bekleyen bireylerin beklediğini bulamaması, iş hayatında kendisine yer bulamaması toplumsal olarak bir çöküntüye dönüşme eğilimindedir. İşsizlik iktisadi bir problem olarak görülse de sonuçları bakımından sosyal yapıda daha fazla probleme neden olmaktadır. İşsizlik sebebiyle toplumda görülen bu sorunları ortadan 
kaldırmanın en başarılı yolu işsizliği en aza indirmektir. Gerekli tedbirler alınmaz ise toplum hem sosyal hem de iktisadi olarak zarar görecektir (Karagöl, 2010: s. 55).

\section{4. İşsizlikle Mücadelede Uygulan Politika Ve Yöntemler}

İstihdam yaratıcı uygulamalar, pasif ve aktif istihdam politikaları olarak incelemeye alınmaktadır. OECD'nin istihdam programları ile ilgili sınıflandırmasında bu politikalar yedi başlık altında incelenmiştir. Bunlar; Aktif istihdam politikaları, Kamu İşe Yerleştirme ve Aracılık Hizmetleri, Mesleki Eğitim, Gençlere Yönelik Politikalar, İstihdam Sübvansiyonu ve Sakatlara Yönelik Politikalardır. Pasif istihdam politikaları ise İşsizlik Sigortası, Erken Emeklilik ve Kıdem Tazminatıdır (Varçın, 2004: s.182).

\subsection{Pasif İstihdam Politikaları ve Uygulama Yöntemleri}

Pasif istihdam politikaları, istihdam yaratmaktan ve işsizlik oranını azaltmaktan çok işsizliğin yol açtığı olumsuzlukları ortadan kaldırmak için işsizlere durumlarına göre ekonomik teminat sunan politikalardır. Pasif istihdam politikaları genel olarak işsizlik sigortası uygulamaları ve işsizlik yardımı olarak ortaya çıkmaktadır (Güney, 2009: s. 154).

İşsizlik sigortası uygulaması uygulanan pasif istihdam politikalarından birisidir. İşsizlik sigortası uygulaması Türkiye'de 25 Ağustos 1999 tarihinde başlamıştır. Prim tahsilâtları yapılması ise 2000 yılında başlamış ve ödemeler 2002 yılının mart ayında gerçekleşmiştir. İşizlik sigortası sisteminden faydalanmak için son 3 yılda toplamda en az 600 gün işsizlik sigortası primi ödemesi yapması ayrıca sigortalı işsizlerin sigorta priminin yattığı son 120 gün sürekli çalışmış olmaları gerekmektedir. Tüm bu şartları taşıyan birey en son basamakta ise işveren tarafından doldurulan işini kaybettiğine yönelik belgeyi İ̧SKUR müdürlügüne teslim etmelidir. $\mathrm{Bu}$ şartları sağlamak çoğu zaman imkânsız olduğu için birçok işsiz işsizlik sigortasından yararlanamamaktadır. Bu sebeple bu tür yasal düzenlemelerin, işsizlik sorunu yaşayan her insana maddi ve manevi anlamda fayda sağlamadığını söylemek mümkündür (Özpınar, Demir ve Keskin, 2011: s. 137).

Bir diğer pasif istihdam politikası ise erken emeklilik uygulamasıdır. Erken emeklilik ile yaşlı işgücünün istihdam dışına çıkarılmasının sağlanması amaçlanarak işyerlerinde potansiyel olarak daha genç işgücünün istihdamının tercih edilmesi amaçlanmaktadır (Varçın, 2004: s. 100). Ancak bu uygulamada belirli bir iş tecrübesine sahip olan emeklilerin tekrar iş piyasasına girdikleri ve genç işsizlerin iş bulma imkânlarının bu nedenle daraldığı gözlenmektedir (Erkekli, 2007: s. 38).

Erken emeklilik uygulamasının kullanıldığı bir başka pasif istihdam politikası çalışma paylaşımıdır. Çalışma paylaşımını uygulamada iki farklı şekilde görmek mümkündür. Birinci şekilde emekliliği yaklaşan çalışanlar emekli edilerek bunlardan boşalan yerlere işsizler istihdam edilmektedir. İkinci şeklinde ise, çalışma süreleri kısaltılıp ve fazla mesai yaptırma imkânlarını zorlaştırarak işverenlerin daha fazla işçi istihdam etmeleri sağlanmaktadır. $\mathrm{Bu}$ politika bir ekonomide belli bir zamanda sabit sayıda iş olduğu ve bu işlerin var olan işgücü tarafından nasıl paylaşılacağına yönelik politikayı belirleyenlerin karar vereceği görüşüne dayanmaktadır (Biçerli, 2004: s. 327).

Pasif istihdam politikası olarak işlev gören başka bir uygulama ise kıdem tazminatıdır. Kıdem tazminatı çeşitli şekillerde ortaya çıktığı için tanımlamalarda da farklılık göstermektedir. İş sözleşmesinin son bulmasıyla birlikte hukuksal bir sonuç olarak doğan kıdem tazminatı, iş kanununda belirtilmiş olan kanuni çalışma süreleri dolduran işçilerin iş sözleşmesinin bir 
sebeple son bulması durumunda işveren tarafindan işçiye veya işçinin kanuni temsilcisine ödenen değerdir (Koç ve Akbıyık, 2011: s. 254). Kıdem tazminatı temel olarak işçinin haklı, işverenin haksız olduğu bir nedenle iş akdinin sona ermesi durumudur. İşverenin haksız olarak iş sözleşmesini tek taraflı ortadan kaldırması neticesinde bir yıl veya daha fazla süre ile çalışan işçiler için ödenmesi yasal görülen kendine özgü bir tazminat olarak da ifade edilmektedir (Günay, 1994: s. 112).

\subsection{Aktif İstihdam Politikaları ve Uygulama Yöntemleri}

Aktif istihdam politikaları, işsizliği en aza indirmeyi ve işini kaybeden kişilerin kısa sürede iş bularak istihdama tekrar katılmalarını amaç edinen iktisadi programlardan oluşmaktadır. Aktif istihdam politikalarının iki temel işlevinden bahsedilmektedir. $\mathrm{Bu}$ programlarda mesleki eğitim, istihdam hizmetleri gibi aktif politikalarla olası bir işsizlik durumunun önüne geçildiği ileri sürülerek programların çalışan üzerinde verim artışı ile gelir sağlama kapasitelerinin yükseltildiği vurgulanmaktadır. Aktif, istihdam politikaları İşsizliğin azaltılması ve çalışan gelirlerinin arttırılmasını amaç edinmektedir. Aktif istihdam programları emeğin çalışmış olduğu ortamın verimliliğinin arttırılması ve işe başlamada firsat eşitliğinin sağlanmasına yönelik olarak planlanmıș birtakım uygulamalardan oluşmaktadır (Dertli, 2007: s. 68, 69).

Kamu işe yerleştirme ve aracılık hizmetleri, emek piyasalarında emeğini arz eden işçiler ile emek talep eden işverenler arasında aracılık etme görevinin esasını oluşturmaktadır. Esas amaç olarak kamu istihdam kurumlarının görevi yapısal işsizliğe engel olmak ve uzun sürede işsizler ile iş bulmakta güçlük yaşayan diğer işsizlerin iş bulmalarını sağlamaktır. Kamu istihdam kurumları etkinliği arttırmakla beraber, iş yaratımı, ücret desteği ve mesleki eğitim verme gibi işe yerleştirme ötesinde diğer aktif istihdam programlarının uygulanmasında da rol almaktadır (Öksüz, 2007: s. 26).

İstihdam sübvansiyonlarında ise devlet, gelişme eğiliminde olan ya da yeni kurulan işletmelere, direkt kredi vermek yerine kamu istihdam büroları vasıtasıyla çalışanlar ücretlerini sübvanse yoluyla destek sunmaktadır. Ücretlerin ve istihdamın sübvanse edilmesi, yapısal işsizlik neticesinde oluşan uzun dönemli işsizleri ve gençleri hedeflemekte, işe alımlarda işe alma maliyetini azaltmak için uygulanmaktadır. İstihdam sübvansiyonları gelişmiş ülkelerin birçoğunda uygulanan önemli bir işgücü piyasası politika aracıdır. Sübvansiyonlar işgücü piyasalarına müdahaleci yaklaşımı benimseyen Fransa, Almanya, İsveç gibi ülkelerin yanı sıra; İngiltere, A.B.D. Kanada gibi Anglo-Sakson türü işgücü piyasalarına sahip ülkelerde uygulanan önemli bir talep yanlı politikadır (Bulut, 2010: s. 20).

Aktif istihdam politikası uygulamalarının başka bir şekli mesleki eğitim verme ve gençleri teşvik etme uygulamalarıdır. Mesleki ve teknik eğitimin temel amacı, iş piyasasında çalışacaklara belli bir işi veya bir mesleği yapmak için lazım olan beceri ve yetkinlikleri kazandırmaktır. İşletmeler açısından mesleki ve teknik eğitim, işletmelerin verimliliğini, rekabet kabiliyetini, araştırma ve inovasyon kapasitesini güçlendirir. İş kalitesinin artmasında ve çalışan moralinin yükselmesinde mesleki eğitimin rolü fazladır. Mesleki ve teknik eğitim toplumsal açıdan ekonomik gelişme, refah, yoksulluğu önleme ile sosyal uyum şartlarını güçlendirir (MESS, 19.03.2013).

$\mathrm{Bu}$ bağlamda mesleki eğitim kurumlarının temel görevleri aşağıdaki şekilde sıralamak mümkündür (Aksoy ve Mütevellioğlu, 2010, s. 23, 24);

1. Bir ildeki istihdam ve mesleki eğitimi yönlendirecek politika belirlemek 
2. İl içerisinde talep edilen işgücünü ve meslek eğitiminde duyulan ihtiyacı belirleyerek işgücü piyasası araştırmaları yapmak, elde edilen verileri değerlendirip yayınlamak,

3. Mesleki eğitime yönelik olarak Milli eğitim müdürlüğünce gönderilen planlamanın işgücü piyasası ihtiyacı doğrultusunda hazırlanması için çalışma sonuçlarına yönelik önerilerde bulunmak,

4. Verilen meslek eğitimlerinde ortaya çıkacak olan uyuşmazlıkların çözüme ulaşmasında gerekli desteği göstermek

5. Mesleki eğitim, istihdam konularında kurum ve kuruluşlarca iletilen önerileri görüşerek sonuca bağlamak,

6. İlgili kurum ve kuruluşları istihdamı koruyucu, geliştirici ve işsizliği önleyici tedbirleri belirleyerek uyarmak,

7. İl Milli Eğitim Müdürlüğü ve İŞKUR tarafindan hazırlanan işgücü yetiştirme planların ilin sosyal yapısını göz önüne alarak onaylamak ve uygulamaların sonuçlarını gözlemlemek,

8. Tüm maddelerin ve hükümlerin eksiksiz olarak il içerisinde uygulanması hususunda gerekli önlemleri almak.

Aktif istihdam politikalarının bir diğeri engellilere yönelik uygulanan istihdam politikalarıdır. Engellilerin çalışma hayatında var olmasına yönelik çalışmalarda bu doğrultuda yapılmaktadır. Türkiye'de de engellilerin çalışma hayatı içerisinde yer alması için bazı hukuki düzenlemeler yapılmıştır. İşveren çalsştırmak istediği iş̧̧iyi seçmek ve iş̧̧i de çalışmak istediği işverenle iş sözleşmesi yapmakta özgürdür. Fakat devlet sosyal devlet olma olgusundan hareketle yasal düzenlemelerle kamusal yararını gözeterek çalışma ilişkilerindeki iş sözleşmesi serbestisine müdahale etmektedir. İş sözleşmesi serbestisini sınırlayan, yani zorunlu istihdamın uygulamasını gerekli kılan hususlardan biri de engelli işçi istihdamıdır (Temir, 20.03.2013).

4857 sayılı İş Kanununun 30. maddesinde yer alan hukuki düzenlemeye göre, İşverenlerin elli veya daha fazla işçi çalıştırdıkları işyerlerinde her yılın ocak ayı başından itibaren yürürlüğe gireceği belirtilmiştir. Bakanlar Kurulunca belirlenecek oranlarda engelli ve eski hükümlü ile 3713 sayılı Terörle Mücadele Kanununun ek 1. maddesinin (B) fikrası uyarınca istihdamı zorunlu olan terör mağduru işçiyi mesleki, bedeni ve ruhi hallerine uygun işlerde çalıştırmakla yükümlüdürler. Bu kapsamda çalıştırılacak işçilerin nitelikleri, hangi işlerde çalıştırılabilecekleri, bunların işyerlerinde genel hükümler dışında bağlı olacakları özel çalışma ile mesleğe yöneltilmeleri, mesleki yönden işverence nasıl işe alınacakları, Adalet Bakanlığı ile Çalı̧̧ma ve Sosyal Güvenlik Bakanlığınca çıkarılacak yönetmelikle düzenlenir. Yer altı ve su altı işlerinde engelli işçi çalıştırılamaz ve yukarıdaki hükümler gereğince işyerlerindeki iş̧̧i sayısının tespitinde yer altı ve su altı işlerinde çalışanlar hesaba dâhil edilmez (TBMM, 20.03.2013).

\section{5. İstihdam Üzerine Uygulanan Teoriler}

Klasik ve Neo Klasik düşünürlerin istihdam kavramına gereken önemi vermeyişi istihdamın teori olarak henüz yeni yeni anlaşılmaya başlanan bir durum olarak karşımıza çıkarmaktadır. Klasik ve Neo Klasik düşüncede dengenin kendiliğinden gerçekleşeceği yani görünmez el vasıta ile işsizliğin kendiliğinden ortadan kalkacağı bir durum olarak görülmesi bu ilgisizliğin temel nedeni olarak görülmektedir. Günümüz şartlarında iktisadi bir karar olarak alınan eşit işe eşit ücret uygulaması, Klasiklerin fiyatların tümüyle ve tamamen elastikiyete sahip olduklarını düşüncelerini ötelemektedir. Bu durum Klasik ve Neo Klasik düşünürlerin 
istihdamı teorik bir konu olarak ne kadar göz ardı etmiş olduklarını düşündürmektedir (Y1ldirım ve Karaman, 2001: s. 113).

Klasik ve Yeni Klasik görüşün tamamen kabul gördügü evrelerde görülen iktisadi krizlere yönelik genel denge düzeyinde geçici bir değişimin olduğu ve bu durumun bir müddet sonra sistem tarafından kendi kendini telafi edeceğini savunmuşlardır. Her ne kadar iktisadi sistemin kendini koruyacağı düşüncesi savunulsa da Büyük Bunalımın ardında durumun böyle olmadığı üretimin sekteye uğradığı, işçilerin işsiz kaldığı dönemlerde iktisadi sistemin kendiliğinden dengeyi sağlamadığı hususunda bu iktisadi düşünürlere yönelik yapılan eleştiriler haklı bulunmaya başlanılmıştır (Demir, 1996: s. 20).

Klasik düşüncenin giderek önemini kaybettiği buhran sonrası dönemde ekonominin kendiliğinden dengeyi sağlayamayacağı, iktisadi sistemin kusursuz işlemesi için devlet müdahalesinin gerekli olduğu düşüncesi savunan J. M. Keynes, istihdam kavramının iktisadi teoride gereken değeri görmesine öncülük etmiştir. Buna karşılık Klasik düşüncenin istihdamla ilgili görüşler değer kaybetmemiştir. Keynesyen görüş Klasik düşünülere yönelik olarak yaptığı eleştiriler sayesinde günümüzde de geçerliliğini sürdürmektedir (Pekin, 2007: s. 105).

\subsection{Klasik ve Neo-Klasik İstihdam Teorileri}

İktisat teorilerinin temel olarak Yunan uygarlığından daha önceleri var olduğu bilinmektedir. $\mathrm{Bu}$ bilginin varlığına rağmen günümüz iktisadının temellerini Adam Smith'in attığı kabul edilmektedir. Sanayi Devrimi öncesinde temel üretim araçlarıyla gerçekleştirilen üretim terk edilerek büyük buharlı makinaların kullanıldığı sanayi tipi üretim aşamasına geçilmiştir. Daha fazla ürünün daha kısa sürede üretimi sermaye birikimini arttırmıştır. Bu süreç çerçevesinde Klasik iktisatçılar, iktisadi sistemin nasıl işlediği, sistemin işleyişi yönünde ne gibi kanunların etkili olduğu konusunda düşünce üretmeye başlamıştır. Klasik iktisatçılar bireye ekonomik olarak bir değer atfederek akıllı ve iktisadi her bireyin önce kendi refahını sağlayacağını böylece bir refah birikimi olacağını ve sonuçta bu birikimin toplumsal refah düzeyinde artış sağlayacağını öne sürmektedir (Dinler, 1997: s. 280).

Klasik iktisat teorisi tam istihdam varsayımını "üç temel kuram" üzerine inşa etmişlerdir. Bunlar "Mahreçler Yasası", "Faiz Teorisi” ve "Ücret Teorisi”dir.

\subsubsection{Mahreçler Yasası}

J. B. Say, "Say Yasasını" her arz kendi talebini yaratır şeklinde ifade etmektedir. Say’a göre ekonomik sistemde var olan bir talep yetersizliğinden dolayı işsizliğin meydana gelmesi mümkün görülmemektedir. Klasik görüş ekonomide tam istihdamın oluşmasına yönelik bir engelin var olabileceği görüşünü kabul etmemektedir. Çünkü Klasiklere göre yapılan her üretim bir tüketimle sonuçlanacaktır. Böyle bir durumun varlığı talep azlığı nedeniyle ortaya çıkacak olan bir işsizliğe neden olmamaktadır. Bu yasa içerisinde para iktisadi sistemde sadece bir araç olarak görülmektedir. Bu nedenle de ekonomiye konu olacak bir malın maddi karşılığı yine bir başka olmalıdır düşüncesiyle takasta malın malla değişimi gerekli görülmektedir (Özgüven, 1997: s. 107, 108).

Klasik iktisatçılar takas yolu ile yürütülen bir iktisadi faaliyette Say Yasası'nın böyle işleyeceğini belirtmiş̧lerdir. Şayet mübadelesi yapılacak mal para olursa yasa şu şekilde işlemeye devam edecektir. Belirli bir üretim sonucu elde edilen parasal gelir sürekli olarak harcamaya tabi tutulacaktır. Parasal gelirde görülen bu harcama eğilimi düzenli olarak devam 
ederse yine her arz kendi talebini yaratmayı başaracaktır. Bu şartlarda üretilen bütün malların talep edileceği ve artan talebi karşılamak için üretim seviyesinin artacağı düşünülmektedir. Tüm bu mekanizma olağan olarak işlemeye devam ederse iktisadi sistem kendiliğinden tam istihdamı yakalayacaktır. Piyasada böyle bir durumla karşılaşan firmalar üretimlerini kısarak tam istihdam seviyesini koruyacaklardır. Dengesizlik talep yetersizliğinden dolayı kaynaklanırsa üreticiler arzlarını azaltacaktır (Dirimtekin, 1981, s. 210, 212). Bu şekilde işleyen sistem dengesizliğin oluşmasına imkân vermeyecektir.

\subsubsection{Faiz Teorisi}

Klasik iktisatçılar faizi, harcama yapmamanın maddi bir getirisi olarak görmektedir. Onlara göre faizin oluşmasına tasarrufta bulunma düşüncesi sebep olmaktadır. Klasik düşünürlere göre bireyler yalnızca faiz getirisi elde edebilmek düşüncesiyle tasarrufta bulunurlar (Pekin, 1996 s. 116). Gelirin harcamaya ayrılmayan kısmı faiz sayesinde yatırıma dönüştürülebilir. $\mathrm{Bu}$ durumda her tasarrufun bir yatırıma dönüşeceği düşüncesiyle tasarruf yatırım eşitliği öne sürülmektedir (Aren, 2005, s. 17).

Bir tasarrufun yatırım olarak sisteme girişi faiz oranı tarafindan belirlenmektedir. $\mathrm{Bu}$ bakımdan faiz, yatırım yapma amacı ile tasarrufta bulunma düşüncesinin bireylerce kabuk edilmesini sağlamaktadır. Tasarruf, yatırım yapılacak olan kaynaklara yönelik bir arz olarak da düşünülebilir. Klasik iktisatçılar, tasarruflarda meydana gelecek olan olağan artışlar neticesinde faiz haddinin buna bağımlı olarak düşeceğini, bu düşüş neticesinde toplam maliyette bir azalışın oluşacağını ve bu sayede gelirin artacağını savunmaktadırlar. Gelir artışı firmalara tasarruf etme konusunda bask1 yapacaktır. Bu bask1 neticesinde üreticiler daha fazla kar elde edebilme arzusu ile üretimlerini genişletecek ve böylece çalışma arzusu ve kabiliyeti olan bireylerin istihdama daha fazla dahil olacağı düşünülmektedir (Özgüven, 1997: s. 400, 401).

\subsection{3. Ücret Teorisi}

Klasik iktisatçılara göre, emek arz ve talebinin kesiştiği yer ücret miktarı ve istihdam düzeyini belirler ve bu noktada ekonomi tam istihdamdadır. Emek talebi, bir işletme ya da ekonominin üretime almak istediği emek miktarıdır ve klasik modelde reel ücretlerin düzeyine bağlıdır. Hem firma düzeyinde hem de makro düzeyde emek talebi, reel ücretlerin azalan fonksiyonudur. Emek arzı ise, üretime dahil edilen üretim faktörlerinden biri olan emeğin istihdam piyasasına çıkışını ifade eder. Klasik düşüncede emek arzı, mal arzı gibi emeğin fiyatına, yani reel ücretlere bağlıdır. Klasik düşünceye göre emek arzının belirleyicisi nüfustur, J.S.Mill bunu açıkça emek arzı nüfustur biçiminde ifade etmektedir (Ünay, 1996: s. 268).

Klasik istihdam teorisine göre nüfus artışı emek arzını yükselterek işsizliğe neden olmakta ve bunun sonucunda ücret düzeyi düşmektedir. Ücretlerin düşmesi ise, nüfusu yeniden sınırlamaktadır. Diğer yandan ücretler maliyetlere dâhil edildiğinden ücretlerin düşmesi, fiyatları da düşürmekte ve mallara karşı olan talebi artırmaktadır. Artan talebin karşılanabilmesi için, yeniden işsizler işe alınmakta ve istihdam hacmi genişlemektedir (Türkbal, 2005: s. 386).

Klasiklere göre ücret, işverenler bakımından işin marjinal verimine, isçiler bakımından da işin marjinal emeğine eşittir. Tam istihdam seviyesine yaklaştıkça işin marjinal verimi azalan verimler kanunu nedeniyle azalır. Buna karşılık işin marjinal emeği, istihdam seviyesi 
yükseldikçe artar. Klasiklere göre ücret, işin marjinal verimi ile marjinal emeğinin eşit olduğu noktada oluşur ve tam istihdam seviyesini karşılar (Aren, 1960: s. 19).

Klasik görüş, gayri iradi işsizlik sorununun varlığını kabul etmez. Çalışmak isteyen herkes, cari ücret seviyesinin üzerinde iş bulabilmektedir. Buna rağmen ekonomide işsizler varsa, bu onların marjinal verimliliklerinin üstünde ücret talep etmelerinden doğmaktadır (Pekin, 2007 s. 136).

Klasik teorilerin varlığını sürdürmeye devam eden Yeni Klasikler, bu teorilerin devamıyla birlikte Klasik görüşe önemli katkılar da sağlamışlardır. Yeni Klasiklerin en büyük başarısı tüketime konu olan her yeni birim bir malın sağlayacağı yarar ve üretime konu olan her yeni birim üretim faktörünün sağlayacağı gelirin ne kadar süre ile devam edeceği görüşü olmuştur. Marjinal fayda ve marjinal gelir görüşleri çerçevesinde Yeni Klasiklere Marjinal İktisatçılar da denilmektedir (Alkin, 1984: s. 488).

Yeni Klasikler düşüncelerini, Klasik iktisadi görüşün aksine rasyonalite ve maksimum yarar üzerine temellendirmişlerdir. Klasik iktisatçılar iktisadi teoriyi bölüşüm ile değerlendirirken marjinalistlerin teori konusu seçim olmuştur. Yeni Klasiklerin bir başka katkısı ise makrodan mikroya bir geçiş süreci oluşturarak uzun dönem yerine kısa dönem analizler yapmak olmuştur (Bekiroğlu, 2010: s. 21).

\subsection{Marksist İstihdam Teorisi}

Emek piyasasında bir arz fazlasının sürekli olarak bulunduğunu öne süren Marksist Teori, işsizliğin kapital unsurların ortaya çıkardığı en önemli sorunlardan biri olarak görmektedir. Emek arz eden bireylerin oluşturduğu arz fazlalığı Marks tarafindan işsizler olarak nitelendirilmektedir. Marksist Teoriye göre emek arzı durağan olmayan ve sürekli artış gösteren bir faktördür. Hızlı nüfus artışı, göçle gelen işgücü, sadece ev işlerinde çalışan kadınlar bu arz fazlasının oluşmasında en büyük etken olarak görülmektedir. Marksist düşünce sistemi bakımından üretim sürecinde gözlenen değişimler, hızlı nüfus artışı ve göç işsizliği arttıran unsurlar olarak görülmektedir (Onaran, 2000: s. 199).

Marksist Teoride yığın işsizliğine neden olan iki ana unsur vardır bunlardan birincisi sanayi sektöründe yaşanan gelişmelerin istenilen hızda olamaması ve üretimi gerçekleştiren asıl grubun gelişme hızına ayak uyduramamasıdır. İkinci ana unsur ise işini geçici olarak kaybeden ve halen çalışmaya devam eden işçiler arasındaki ilgiden kaynaklanmaktadır. $\mathrm{Bu}$ unsurlar bakımından uzun ve kısa vadede dalgalanmalar görülmesi muhtemeldir. Olası talep fazlası durumlarında çalışmak isteyen sayısının çalışan sayısından fazla olması olağandır. Talepte görülen fazlalık ani üretim süreçleri oluşturarak emeğin değerinde yükselişe neden olacaktır (Satligan, 2008: s. 45, 46).

Marksist Teoriye göre toplam ücret seviyesinde gözlenen artış, işçi üzerinde daha fazla çalışma baskısı oluşturarak emeğin işe adanmış bir köle halini almasına neden olmaktadır. Gelir etme amacıyla daha çok çalışacak olan birey bu koşul altında sosyal hayata, kendine ve yaşama dair inancını kaybedecektir. $\mathrm{Bu}$ durumu açıklamak için ise Marksist Teori yabancılaşma kavramını kullanmaktadır (Hunt, 2005: s. 311).

Üretilen bir malın piyasaya değerini belirleyen en önemli unsurun malın üretimi için kullanılan emeğin nitel ve nicel değeri olduğunu ileri süren Marksist Teori bu düşüncesini emek ve değer kavramları üzerine yoğunlaştırmıştır. Karmaşık bir süreç olan üretim aşamasında bir malın üretimi için farklı mal bileşenlerinin de kullanıldığı bilinmektedir. 
Teori, piyasa fiyatı oluşumunda mal bileşenlerinin içerisinde yer alan bütün bileşen maliyetlerinin göz önünde bulundurulması gerekliliğini belirtmektedir Akyüz, 1980: s. 11).

\subsection{Keyesyen İstihdam Teorisi}

Günümüz iktisadi politikalarının temelini oluşturan Keynesyen Teori, özellikle 1950'li yıllarda tartışılmaya başlamıştır. Klasik İktisadi Teorinin karşılaşılan sorunları açıklamada gerekli başarıyı gösterememesi, Keynes'in modern istihdam teorisi olarak anılan bu teoriyi ortaya atmasını kolaylaştırmıştır. Gelişmiş batı toplumlarında görülen durgunluk süreci Klasik ekolün sorunları çözmede yetersiz kaldığını göstermektedir (Ünsal, 2007: s. 32).

Büyük Buhran öncelikle İngiltere'de başlayıp daha sonraları tüm dünyaya yayılmıştır. Tüm dünyada işsizlik oranları yükselmiş ve piyasalar durgunluk sürecine girmişlerdir (Savaş, 1997: s. 742). Sanayileşme başarısını yakalamış olan çoğu ülke 1929 Bunalımı neticesinde krizden zarar görmüştür. Yaşanan kriz işsizlik oranlarında hızlı yükselmiş, artış gösterimine devam etmiştir (Barber, 2008: s. 235). Krizden etkilenen gelişmiş ekonomilerden biriside ABD olmuştur. Dört y1l içerisinde GSYİH's1 93 milyar dolar zarar gören ABD'de işsizlik oranı \% 25 seviyesine yükselmiştir (Ünsal, 2007: s. 32).

Keynes'e göre krizden çıkışın çözümü, sterlin ve altın arasında gerçekleşen mübadele uygulamasından vazgeçilmesiydi. Keynesin öne sürdüğü bu politika önceleri kabul görmedi fakat krizin İngiltere'ye sıçramasıyla İngiltere, Sterlinde devalüasyona gitmiștir. Bu müdahale sonucunda diş ticarette gelişme sağlayan İngiltere ABD'de iktidarda olan Roosevelt'de bir dizi iktisat politikasını yürürlüğe koyarak ekonomik düzene müdahale etmek zorunda kalmıştır. Kamu harcamalarını arttırmak, ücretleri yükseltmek ve doları devalüe ederek ihracatı arttırmak gibi bazı politikaları uygulamaya koymuştur. İngiltere'yi takip eden Almanya'da da bazı önlemlerin alınması Keynes'in görüşlerinde haklılığı ortaya çıkarmıştır (Kazgan, 2005: s. 203, 204).

Piyasanın hiç kimsenin müdahalesi olmadan kendi kendine dengeyi sağlayamayacağını ileri süren Keynes sistemde var olabilecek aksaklıklara karşı her zaman dışarıdan müdahale edilmesi gerektiğini belirtmektedir. Keynes'e göre piyasa tam istihdamı hiçbir zaman kendiliğinden sağlayamaz. Piyasada meydana gelen bir denge eğer müdahale sonucu gerçekleşmemişse bu tesadüfi bir olaydır ve piyasanın bu şekilde dengede kalması uzun sürmeyecektir. Klasiklerin ekonominin tam istihdamda dengede olacağı görüşüne karşılık olarak ekonomide dengenin her zaman eksik istihdamla sağlanabileceğini söylemektedir (Ünsal, 2007: s. 33).

İktisadi Teoriye katkısını toplam talep kavramından anlayabileceğimiz Keynes, bunun yanında efektif talep kavramını da kullanarak iktisadi literatüre katkıda bulunmuştur (Dirimtekin, 1981: s. 206). Burada efektif talep mal ve hizmet temini içi ödenen toplam bedelin ne kadar olduğunu açıklamaktadır. Bu çıkarımdan hareketle bir toplumda mal ve hizmet temini için harcanan parasal değerin milli gelire eşit olması söz konusu olmaktadır (Üstünel, 1990: s. 190, 191).

Genel Teori'sini ortaya atarken genellikle işsizlik üzerine değerlendirmeler yapan Keynes, enflasyon üzerine genel değerlendirmeler yapmak yerine ikinci dünya savaşı yıllarında savaş finansmanı üzerine yayımladığı bir makalede enflasyonuna dair düşüncelerini açıklamıştır. Keynes, teorisi içerisinde işsizliğe yönelik gerekli değerlendirmeleri yapamadan hayatını kaybetmiştir. Fakat bu eksiklik Phillips tarafından ortaya konan bir teori ileri giderilmektedir (Ünsal, 2007: s. 34). 
Araştırmalarında var olan gelir ile elde edilebilecek gelir arasında bir eşitliğin söz konusu olabileceğini iddia eden Phillips, ücretin işverene yönelik bir maliyet unsuru olduğunu ifade etmektedir. Bu bakımdan işgücü maliyetinde gerçekleşen bir artışın işsizliği tetikleyeceğini belirtmektedir. Bu yargıya varmasındaki en önemli husus, uzun yıllar boyunca İngiltere'de bu iki değişken arası ilişsinin bu şekilde devam etmesidir. Phillips'in çalışmalarına ek olarak Samuelson ve Solow'un katkısıyla enflasyon oranı ile işsizlik arasında zıt yönlü bir ilişki olarak Phillips Eğrisi kavramı ortaya atılmıştır (Lipsey 1990: s. 115).

Ücretlerde meydana gelebilecek bir değişikliğin emeğin birim maliyetini etkileyerek toplam arz hızında kaymalara neden olacağını ifade eden Phillips, emeğe ödenen ücretin işsizliğin temel belirleyici olduğu hususunda araştırmalara yönelmiştir. Phillips bu araştırmayı yaparken emeğe yönelik talep artışının işsizliğe yönelik azaltıcı bir etki doğuracağını düşünmektedir. Phillips, çalışmasını 19.yüzyılın ortalarına kadar götürmek istemiştir fakat çıktı açıklarındaki veri eksikliği bunu engellemiştir. Bu çalışmalar eşliğinde çalışmalarına devam eden düşünür, ücrette meydana gelen değişiklik ile çıktı açığını ifade edebilecek bir eğriyi ortaya koyabileceğini düşünmektedir. Phillips'i bu eğriyi oluşturmaya iten neden ise çıktı açığında meydana gelebilecek artışların işsizlik oranını düşürebileceği fikrine sahip olmasıdır. Enflasyonist baskı dönemlerinde görülen düşük işsizlik oranları bunun en temel kanıtı olmaktadir (Lipsey 1990: s. 115, 116).

\subsection{Monetarist İstihdam Teorisi}

Para konusunda zamanla gelişen bu yaklaşım "Paracılık" adını almıştır. Monetarist adı ilk olarak bu teorinin kurucularından birisi olan Karl Brunner tarafindan 1968 yılında kullanılmıştır (Savaş, 1997: s. 870). Monetarizm, ekonomik politikaların temelini maliye politikası yerine, para politikası üzerine oluşturmuştur. Milton Friedman 1976 yılında yayınlanan "Paranın Miktar Teorisi Üzerine Çalışmalar" adlı kitabında Monetarizmin temel ilkelerini ortaya koymuştur (Kılıç, 2006: s. 190).

Friedman parayı talep edenleri iki kısma ayırmaktadır. Birincisi parayı değer saklama aracı olarak talep eden servet sahipleri, ikincisi ise parayı bir üretim unsuru olarak talep eden işletmelerdir. Friedman tek bir para talep fonksiyonu için iki kesimi de inceleyerek birleştirmiştir. Monetarist düşünceye göre para arzı ise önemli bir iktisadi politika aracıdır. Enflasyonu önlemek için döviz kurları esnek olmalı ve devlet döviz kurlarına müdahale etmemesi gerektiği görüşü savunulmuştur. Monetarsit görüşe göre etkin olan politika para politikasıdır. Maliye politikası devletin ekonomiye harcamalar yoluyla girmesi neticesinde bile etkisiz kalacaktır. Devlet harcamalarında meydana gelecek bir artış ya da vergilerdeki bir azalma faiz oranlarını yükseltecek ve üretim düzeyinde değişiklik yapmayacaktır. Bu durumda maliye politikasının üretim düzeyini etkilemeyeceği vurgulanmaktadır (Düğer ve Dulupçu, 2000: s. 163).

Moneterist istihdam teorisinin temel düşüncesi ekonomik bunalımların ve enflasyonun para arzında meydana gelen çok hızlı artışlardan kaynaklandığıdır. İstihdam açısından ise fiyat değişmeleri ile ilgili beklentilerin istihdam ve üretim üzerinde hiçbir etkisi olmadığı Friedman tarafından ileri sürülmüştür. Friedman'a göre fertler fiyatların artacağı beklentisiyle emekleri için daha yüksek fiyat talep ederler. Bunun sonucunda enflasyon tarafindan yaratılan istihdam artışı ortadan kaybolur fakat enflasyon varlığını devam ettirir. İşsizlik probleminin enflasyonun arttırılması ile çözüleceği görüşüne halk inandırılabilirse bu olumlu sonuç verir. Aksi takdirde enflasyon yolu ile işsizliği azaltma politikaları, istihdamı azaltıp enflasyonun daha da artmasına neden olarak tepki doğurur. Genel bakıldığında monetarist düşünce ekonomik özgürlük ve liberal bir ekonomi politikası şeklindedir (Kasalak, 2007: s. 21). 


\subsection{Arz Yanlı İstihdam Teorisi}

İlk kez 1976'da ortaya atılmıştır. İktisadi bir ifade olarak arz yanlı iktisat deyimini ilk defa kullanan Virginia Üniversitesi'nden Dr.Stein'dir. Toplam talebe ağırlık veren Keynesyen Teori'ye bir tepki olarak 1970'li yıllarda doğan Arz Yanlı İktisat'in fikirleri, Jude Wanniski'nin çalışmalarında net olarak gün yüzüne çıkmaktadır. Jude Wanniski'nin yanında Robert Mundell ve Arthur B. Laffer de arz yanlı iktisat düşüncesinin gelişiminde, iktisat teorisyeni olarak etkisi olan isimler olmaktadır (Doğan, 2006: s. 254).

Arz yönlü iktisat politikasının temel politik aracı vergi oranları olmuştur. Vergi oranlarının önemli bir politik araç olarak kullanılmasının kaynağı Avusturyalı iktisatçı Colin Clark olmuştur. Clark 1940'ların sonunda yaptığı bir ekonometrik araştırmada vergi yükünün \%25'in üzerine çıkması halinde enflasyonun başlayacağını ileri sürmüştür. Clark'a göre yüksek vergi oranları tasarrufu ve çalışmayı azaltacak, üretimi ve arzı daraltacak bu yoldan da toplam talep toplam arz dengesini bozarak enflasyon oluşumuna neden olacaktır. Clark'ın bu görüşü iktisat politikalarını etkileyememiştir çünkü, sanayi ülkeleri vergi yükünü \%25'in üzerine çıkarmış oldukları halde hızlı gelişmeyi sürdürebilmişlerdir. Buna rağmen vergi yükü ile makro büyüklükler arasındaki ilişkiye ait ekonometrik araştırmalar devam etmiş ve 1975 'te Laffer, Wanniski ve Roberts'ın vardığ 1 sonuçlar Clark'ın görüşünü yeniden güncel hale getirmiştir. Laffer Eğrisi diye bilinen bu görüş iktisat politikalarının temelini oluşturmaya başlamıştır (Savaş, 1986: s. 172).

1970’li yıllarda maliye politikası alanında laffer eğrisi üzerine çeşitli tartışmalar olmaya başlamıştır. Çünkü vergilerin yüksek olması insanların çalışma ve vergi ödeme isteklerini azaltarak, kazandıkları gelirleri vergi otoritelerinden kaçırmalarına neden olmaktaydı. Laffer eğrisin ifade edilen açıklamalara göre daha düşük vergi oranları daha yüksek vergisel gelir elde etmeyi sağlayacaktır. Çünkü vergi yükü az olduğunda insanlar hem gelir elde etmeye hem de elde ettikleri gelirleri kaçırmadan bildireceklerdir (Çukurçayır, 2011: s. 330). Mükelleflere uygulanan vergi oranlarının yüksekliği nedeniyle mükellefin vergi ödemekten kaçınması, başka bir ifade ile vergi kaçakçılığıdır. Şayet otorite mükelleflerin vergi kaçırmalarına gerek duymacakları bir oran üzerinden vergi tahsil etmeye çalışırsa vergi gelirlerinde artış söz konusu olacaktır. Çünkü düşük bir vergi oranı seviyesinde ödeme yapmak mükellefler açısından sorun oluşturmayacaktır.

Ülkemizdeki küçük ve büyük ölçekteki firmaların çalıştırdıkları işçiler için ödemiş olduğu sigorta primi ve özellikle vergi gibi kesintiler işveren açısından büyük bir maliyet olarak ortaya çıkmaktadır. Hükümetlerin, vergi politikaları çerçevesinde vergi oranlarını arttırarak elde edilen vergi gelirlerini yükseltmek istemesi sebebiyle işverenlerin büyük bir vergisel maliyet yükü altına sokulduğu belirtilmektedir. $\mathrm{Bu}$ sebeple istihdam üzerindeki vergisel yüklerin fazlalığı istihdamın, kısmen veya tamamen kayıt dışına kaymasına neden olmaktadır. Bu durumda da sanayinin motor gücü olan imalat sanayiinde istihdam edilenler negatif yönde bir etki altında kalmaktadır (Türkoğlu, 2011: s. 98).

\subsection{Yeni Klasik İstihdam Teorisi}

Ekonomi ile ilgili gelecekle ilgili beklentide bulunmanın rasyonel bir tutum olacağını ifade eden Yeni Klasikler Rasyonalistler olarak da anılmaktadır. Temelleri 70'li yıllarda atılan bu teorinin en önemli temsilcileri Lucas ve Barro'dur. Yapılan her iktisadi işlemin geleceğe yönelik olumu bir beklenti ile yapıldığını savunan Yeni Klasikler teorilerinde bu düşünceyi dikkate almayan teorisyenlere yönelik eleştiriler yapmaktadır. Bu bakımdan Yeni Klasikler piyasada oluşacak olası beklentilerin piyasa üzerinde düzenleyici bir etki yaratmaktan ziyade 
akılcı bir tutum olacağını ifade etmektedirler. Yeni Klasiklere göre politik açıklamaların piyasa üzerinde işsizliği azaltıcı bir etki doğurması mümkün olmamaktadır (Ünsal, 2007: s. 37).

İşsizlik üzerine açıklamalarda bulunan Rasyonalistler piyasada işsizliğin olmayacağını belirmektedir. Yeni Klasikler işgücü piyasasında gerekli görülen kusursuz bilginin maliyet unsuru oluşturmadan kendiliğinden türeyeceğini, her işçinin bir diğer işçinin yaptığ 1 işi tam olarak yapabileceğini, ücret bakımından elastikiyetin olduğunu ve talep miktarında değişikliklerin gözlenmeyeceği ifade etmektedir. Emek arzında meydana gelebilecek bir artış ücretlerde bir azalış meydana getirerek işsizliğin ortadan kalmasına sebep olacaktır (Törüner, 2000: s. 240).

Rasyonalistler ve Klasik düşünürler arasındaki en önemli farkı ortaya koyan düşünce işgücü ücretinin istihdamın temel belirleyicisi olduğunu düşüncesidir. Bu bakımdan gelecekteki ücret beklentisiyle işsiz kalan bireylerin işgücü piyasa dengesini etkilemesi iradi bir durum olarak görülmektedir. Bireylerin böylesi bir tutumda olmalarının nedenini ise bilgi yetersizliğine bağlamaktadırlar (Ataman, 1998: s. 64).

\subsection{Yeni Keynesyen İstihdam Teorisi}

Ekonomik dalgalanmalara son dönemde verilen yanıtlar arasında diğer bir akımda başlıca temsilcileri G. Mankiw, J. Yellen, G. Akerlof, D. Carlton ve J. Stiglitz gibi ünlü isimler olan Yeni Keynesyen Akım'dır. Bu akımın temel dayanağı ücretler ve fiyatların katılığı ve yaşanan şoklar karşısında bu katılığın oluşturduğu dalgalanmalardır. Bu alandaki açıklamalara göre ücret ve fiyat katılığ talep fonksiyonundaki bir şokun reel üretim ve istihdam üzerinde doğrudan etki yapmasıdır. Yani bir talep şoku karşısında ücret ve fiyat katılığı karları yükselterek üretimi ve istihdamı kamçılayacaktır. Bu yaklaşımda ücret ve fiyat yapışkanlığına yol açan bazı sebepler bulunmaktadır. Bunlardan ilki ücret sözleşmelerinin ani ve sık olarak değişmeyip genellikle uzun dönemler dâhilinde yapılmasıdır (Ataç, 2012: s. 16).

Yeni Keynesyen görüş çerçevesinde ücret katılığı düşüncesinin dayandırıldığı diğer bir husus ise ücretlerin işçi sendikaları tarafından yapılıyor olmasıdır. Sendika tarafından belirlenen ücretlerin ani talep şokları karşısında kısa sürede değiştirilmesi mümkün değildir. Ücret katılığına neden olan bir başka görüş de işçilerin iş verimliliğinin yüksek düzeyde tutulabilmesi için piyasada yüksek ücret belirleme kuralıdır. Bu modelde ücretler piyasa fiyatının üzerinden saptanmış olduğundan kısa süreli şokların etkisi söz konusu olmayacağı için ücret katılığı söz konusudur. Ücret ve fiyat katılığının bir başka nedeni ise katalog fiyatı olarak bilinen, piyasada fiyat değişmelerinin belirli eşiği aşmadığı sürece fiyatların sabit seviyede tutulduğu durumdur. Piyasa fiyatında oluşan değişmeler karşısında, fiyat listelerinin değiştirilmesi ve buna benzer nedenlerle ürün fiyatlarının değiştirilmesi firmalara maliyet yüklüyorsa düşük fiyat değişmelerinde ürünlerde fiyat ayarlamasına gidilmemesi söz konusu olabilir. Bu piyasa şokları üretim ve istihdam üzerinde esnek fiyatlama sistemine göre daha önemli etki yapar (Ataç, 2012: s. 17).

Yeni Keynesyenler makro iktisadi analiz yaparken bunu mikro ekonomik temelleri dikkate alarak yapmayı amaçlamışlardır. Klasik Phillips Eğrisi geciken enflasyon değerleri ile çıktı açığı veya işsizlik ilişkisi ile ilgilenmektedir. Yeni Keynesyen teori ile oluşturulan Phillips eğrisi ise geçmiş ve beklenen enflasyonun nasıl belirlendiği ve cari enflasyon oranının çıktı açığı ile mi yoksa reel marjinal maliyeti ile mi açıklandığına yönelik sorulara cevap aramaktadır. Yeni Keynesyen Phillips eğrisi muhtemel olacak enflasyon oranı ve marjinal maliyetin bir fonksiyonudur. Marjinal maliyet veri iken enflasyon beklentisinde meydana 
gelen bir düşüş gelecekte enflasyonu da düşürecektir. İstihdamı değiştirmeden enflasyonu etkilemek bu şekilde mümkün olacaktır (Korkmaz, 2010: s. 142).

NAIRU adıyla kullanılan işsizlik kavramı enflasyon oranı üzerinde artış yaratmayacak bir durumu ifade etmek amacıyla kullanılmaktadır. Bu durum özetle elde edilebilir gelir seviyesinde gözlenebilecek muhtemel işsizlik seviyesi olarak anlatılmaktadır. Bu açıklamalar neticesinde iktisadi sistemin tam istihdam düzeyinde olduğu durumlarda dahi işsizliğin var olabileceği anlaşılmaktadır (Lipsey 1990: s. 324).

\subsection{Yapısalcı İstihdam Teorisi}

İktisadi kalkınma alanında öncülük eden ekonomistler, gelişimini sürdüren ülkelerin önlerindeki engelleri aşabilmeleri için aşmaları gerekli olan iki hususun varlığından söz ederler. Bunlardan ilki, iktisadi hayatta devletin aktif olarak görev yapması, ikinci ise sistemde yeni düzenlemelerin yapılmadığı takdirde uluslararası iktisadi ortamın gelişmekte olan ülkelerin kalkınması için uygun bir yapıyı ortaya koymadığı sorunudur. Bu görüşler 1950 ve 1960'lardaki kalkınma iktisadı teorisinde kendisine yer bularak yapısalcı yaklaşım olarak değerlendirilmektedir. Yapısalcıların temel görüşü, piyasada gözlenen başarısızlıkların az gelişmiş ekonomilerin genel özelliği olduğu ve bu özelliğin hızlıca terk edilemeyeceği şeklindeki tespitlerinden oluşmaktadır. Yapısalcılar işsizlik sorununun çözümlenebilmesi için iki aşamalı bir öneride bulunmaktadırlar (Şen, 20.04.2013):

- İlk aşamadan kasit Keynesyen para ve Keynesyen maliye politikalarının uygulanması içeren bir öneridir.

- $\quad$ İkinci aşamada ise yapısalcı politikaların işgücünün formasyonunu geliştirmeye, akışkanlık derecesini yükseltmeye ve bölgesel farklılıkları azaltmaya yönelik çabaları barındırmaktadır.

$\mathrm{Bu}$ çabalar sonucunda, işgücünün niteliği yükselecek olup daha nitelikli olan emek unsurunun, iş bulma ve çalışma imkânları artacaktır. Diğer yandan bölgesel kalkınmanın gerçekleşmesi, istihdam edilenlerin çalışma koşullarında belirgin iyileştirmeler sağlayacak ve işsizliği azaltıcı yönde bir politika olarak önerilmektedir (Lordoğlu ve Özkaplan, 2003: s. 407).

Arthur Okun tarafindan ortaya atılan yasa reel büyüme ile eksik istihdam oranı arasındaki ilişkiyi belirtip Okun Yasası olarak bilinmektedir. Okun Yasasına göre bir yıl boyunca oluşan trend oranı üzerinde reel GSYH deki her \%2.2'lik büyüme sonucu işsizlik oranında \%1'lik bir azalma durumu söz konusu olacaktır. Aslında \%2.2'ye \%1 ilişkisinin yasa olarak sunulması abartılı bir durum olarak nitelendirilebilir. Ekonominin potansiyel büyüme oranının yılda \%3, işsizlik oranının $\% 6$ olduğunu ve işsizlik oranının \%3'e indirilmek istediğini düşünelim. Bu durumda işsizliği her yıl \%1 oranında düşürmek için reel GSYH'nin normal \%3'lük trendinin üzerinde 2.2 büyütülmesi gerekli olacaktır (Parasız, 2008: s. 450).

Okun yasasının farklı ülkeler ve farklı dönemlerde aynı sonucu vermeyişi, ülke ve dönem koşullarının da dikkate alınması gerekliliğini ortaya çıkarmıştır. Türkiye'de özellikle 2002 yılından sonra hızlı verimlilik artışları yaşanmış olmasına rağmen işsizlik oranının azalmadığı görülmektedir. Bu sebeple Okun Yasası ekonomide yapısal bir özellik olarak değil temel bir iktisadi kural olarak düşünülmelidir (Demirgil, 21.04.2013). 


\section{Sonuç}

İşsizlik çoğu insanın hayatında katlanılması güç ve istenmeyen bir durum olarak ortaya çıkmaktadır. Bu yüzden istenen durum her zaman istihdamın artması yönündedir. Gelişmekte olan toplumlarda gözlenen hızlı nüfus artışı her bireyin istihdam edilmesini imkânsız kılmaktadır. Bu durumda istihdamı bir ayrıcalık fertler arasında bir farklılık olarak görmekten kaçınmak mümkün değildir. Gelişen ekonomik şartlarla birlikte eğitim seviyesi yükselen bayanların istihdam içerisinde daha aktif rol alması işsizlik oranın artmasına neden olmaktadır.

İstihdamın böylesine ayrıcalıklı bir hal aldığı günümüzde bireyler seçicilikten uzaklaşmaktadır. Gelinen nokta, işin ne olduğu, hangi şartlarda kimler tarafından yapılabildiğinden çok ne pahasına olursa olsun bir işe sahip olmanın daha tatmin edici olduğudur. Bu yüzden işin ve çalışma şartlarının önemi giderek azalmakta, insanlar iyi kötü bir iş sahibi olma telaşına düşmektedir. İş aramada geçen sürenin fazla oluşu insanları belirli bir gelirden mahrum bırakmaktadır. Çalıştıkları süre içerinde bu gelirden mahrum kalan insanlar işsizlik işle geçen süre boyunca bir takım harcamalarda yapmaktadır. Kaybolan bu gelirin ve yapılan harcamaların finanse edilebilmesi için işin niteliksel değerinden çok gelir getirici yönü dikkate alınmaktadır. Devlet bu konuda İŞKUR aracılığ 1 ile bir takım iş başı eğitim programları uygulasa bile bu programlar sorunun giderilmesi için yeterli değildir.

İstihdam ve işsizlikten kaynaklanan sorunlar önceleri sadece az gelişmiş ülkelerin ekonomik gelişmesini ve sosyal yaşamını etkileyen problemler olarak görünürken, 2000'li yıllarda etkisini daha çok göstermeye başlayan küreselleşme ile tüm dünyayı ilgilendiren bir sorun haline dönüşmüştür. Dünyadaki hızlı değişim ve gelişmeyle beraber birçok sektör daha önemli hale gelmiş bununla beraber bazı sektörlerin ise önemi azalmıştır. Diğer yandan iktisadi etkileri ulusal ve bölgesel sorunlar olmaktan çıkıp, dünya genelinde ortak sorunlar üretmesi, tüm ülkelerin istihdam ve işsizlik olgularını tekrar gözden geçirmelerini gerekli kılmıştır. Bu sürecin olumsuz sonuçlarının önlenebilmesi bakımından, istihdam politikalarının ve işgücü piyasalarının yeniden değerlendirilip geliştirilmesiyle beraber daha modern piyasaların oluşturulması gerekliliği de ortaya çıkmıştır. 


\section{REFERENCES}

- AKSOY, Beyhan ve Nergis Mütevellioğlu (2010). "İşsizlikle Mücadelede İl İstihdam ve Mesleki Eğitim Kurumlarının İşlevi", Çalışma İlişkileri Dergisi, 1(1): ss.13-35.

- AKYÜZ, Yılmaz (1980), "Emek-Değer Teorisi ve Nitelikli İşgücü Sorunu", Üniversitesi Siyasal Bilimler Fakültesi Yayınları, Ankara.

- ALKİN, Erdoğan (1984), "İktisat", Filiz Kitabevi, İstanbul.

- ARDIÇ, Oğuzhan (2004), "Makro İktisat", Seçkin Yayıncılık, Ankara.

- AREN, Sadun (1960), "İstihdam, Para ve İktisadi Politika", Ajans Türk Matbaası, Ankara.

- ATAÇ, Beyhan (2012), "Maliye Politikası-1", Anadolu Üniversitesi Yayınları, Eskişehir.

- ATAMAN, Berrin Ceylan (1998), "İşsizlik Sorununa Yeni Yaklaşımlar", Ankara Ü. Siyasal Bilgiler Fakültesi Dergisi, 53(1), ss.59-72.

- BARBER, William J. (2008), "İktisadi Düşünce Tarihi", (Çev. İhsan Durdu), Metropol Yayınları, İstanbul.

- BEKİROĞLU, Cemil (2010), "Türkiye'de İşsizlik Sorunun Çözümlenmesinde Uygulanan Ekonomi Politikalarının Analizi", Kadir Has Üniversitesi SBE Yayınlanmamış Yüksek Lisans Tezi, İstanbul.

- BİÇERLİ, Mustafa Kemal (2004), "İşsizlikle Mücadelede Aktif İstihdam Politikaları", Anadolu Üniversitesi Yayınları, Eskişehir.

- BOZTEPE, Yenal (2007), "Türkiye'de İşsizlik Kavramı ve İşsizliğin Ortadan Kaldırılması ile İlgili Bir Model Oluşturulması", Yıldız Teknik Üniversitesi SBE Yayınlanmamış Yüksek Lisans Tezi, İstanbul.

- BULUT, Selahattin (2010), "Türkiye'de Aktif İstihdam Politikası Aracı Olarak Düzenlenen İşgücü Eğitim Kurslarının İstihdam Açısından Belirleyiciliği", Gazi Üniversitesi SBE Yayınlanmamış Yüksek Lisans Tezi, Ankara.

- ÇUKURÇAYIR, Sinan (2011), "Laffer Eğrisi Doğrultusunda Vergi Oranları, Vergilendirilebilir Gelir ve Vergi Gelirleri Arasındaki İlişkinin Anlaşılması", Maliye Dergisi, 161: ss.326-336, Ankara.

- DEMIR, Ömer (1996), "Kurumcu İktisat", Vadi Yayınları, Ankara.

- DEMİRGIL, Hakan "Okun Yasasının Türkiye için Geçerliliğine Dair Ampirik Bir Çalışma", $\quad$ http://dergipark.ulakbim.gov.tr/uaifd/article/view/5000051260. (21.04.2014).

- DERTLİ, Nail (2007), "Aktif İstihdam Politikaları Eleştirel Bir Yaklaşım", Ankara Üniversitesi SBE Yayınlanmamış Yüksek Lisans Tezi, Ankara.

- DIINLER, Zeynel (1997), "İktisada Giriş", Ekin Yayınevi, Bursa.

- DİRIMTEKIN, Halil (1981), "Makro İktisat", Bizim Kitapevi, İstanbul.

- DOĞAN, Seyhun (2006), "Keynesyen Teoriye Bir Tepki: Arz Yanlı İktisat", Selçuk Üniversitesi İIBF Sosyal ve Ekonomik Araştırmalar Dergisi, 12: ss.253-272.

- DÜĞER, İsmail Hakkı ve Murat Ali Dulupçu (2000), İktisata Giriş, Graphics Yayınları, İstanbul.

- ERKEKLİ, Ferit (Eylül 2007), "İstihdam Politikaları, Esneklik ve Özel İstihdam Büroları", TİSK İşveren Dergisi, ss.36-41.

- GÜNAY, Cevdet İlhan (Nisan 1994), "Kıdem Tazminatının Hukuki Niteliği ve Askerlik Borçlanmasının Kıdem Süresine Etkisi", Yargıtay Dergisi,(1-2), ss. 108-120. 
- GÜNEY, Alptekin (2009), "İşsizlik, Nedenleri, Sonuçları ve Mücadele Yöntemleri", Kamu-İș Dergisi, 10(4): ss.135-159.

- GÜR, Timur Han ve Emel Ural (2004), “Türkiye’ de Kentlere Göçün Nedenleri”, Hacettepe Üniversitesi İIBF Dergisi, 22 (1), ss. 23-38.

- HUNT, Emery Kay (2005), "İktisadi Düşünce Tarihi", (Çev. Müfit Günay), Dost Kitapevi, Ankara.

- KARAGÖL, Erdal Tanas (Mayıs 2010), "İşsizliğin Sosyal Maliyeti". Anlayış Dergisi, 84(-), ss.55-57.

- KASALAK, Murat Alpaslan (2007), "Avrupa Birliği'ndeki İstihdam Stratejileri ile Türkiye'deki İstihdam Stratejilerinin Ekonomik Anlamda Karşılaştırılması", Süleyman Demirel Üniversitesi, SBE Yayınlanmamış Yüksek Lisans Tezi, Isparta.

- KAZGAN, Gülten (2005), "Türkiye Ekonomisinde Krizler (1921-2001) Ekonomi Politik Açıdan Bir İrdeleme", Bilgi Üniversitesi Yayınları, İstanbul.

- KILIÇ, Ramazan (2006), "İktisadi Düşünce", Siyasal Kitabevi, Ankara.

- KOÇ, Muzaffer ve Nihat Akbıyık (2011), "Kıdem Tazminatı ve Kıdem Tazminatı Fonunun İktisadi ve Sosyal Sonuçları", Süleyman Demirel Üniversitesi, İ̈BF Dergisi, 16(3), s.28-253.

- KORKMAZ, Suna (2010), "Yeni Keynesyen Phillips Eğrisinin Türkiye’ye Uygulanması", Bülent Ecevit Üniversitesi Uluslararası Yönetim İktisat ve İşletme Dergisi, 6(11), ss.141-162.

- KURT, Şenol (2005), "İşsizliğin Sosyo Ekonomik Analizi: Sosyal Açıdan Türkiye Örneği", İstanbul Üniversitesi, SBE Yayınlanmamış Yüksek Lisans Tezi, İstanbul.

- LİPSEY R. G. (1990), "İktisat 2", (Çev. Ahmet Çakmak), Bilim Teknik Yayınevi, İstanbul.

- LORDOĞLU, Kuvvet ve Nurcan Özkaplan (2003), "Çalışma İktisadı", Der Yayınları, İstanbul.

- MESS, Mesleki Eğitim Vakfı, "Yaygın Eğitim Kapsamında Mesleki Eğitim", http://www.messegitim.com.tr/ti/579/0/YAYGIN-EGITIM-KAPSAMINDAMESLEKI-EGITIM SISTEMI.(19.03.2013)

- NOYAN, Aydın (Nisan 2012), "İşsizlik, Beveridge Eğrisi ve Türkiye İşü̈cü Piyasasına İlişkin Bir Değerlendirme", Dumlupınar Üniversitesi Sosyal Bilimler Dergisi, 32(2), s.119-134.

- OKTAY, Ertan (1998), "Makro İktisat Teorisi ve Politikası", Gazi Kitapevi, Ankara.

- ONARAN, Özlem (2000), "Türkiye'de Yapısal Uyum Sürecinde Emek Piyasasının Esnekliği", Toplum ve Bilim Dergisi, 86(-), ss.211-240.

- ÖKSÜZ, Davut (2007), "IŞSUR'un İşe Yerleştirme Hizmetleri, Özel Sektör Üzerindeki Etkisi ve Etkinliğinin Arttırılması", Çalışma ve Sosyal Güvenlik Bakanlığı, Türkiye İş Kurumu Genel Müdürlüğü, Uzmanlık Tezi, Ankara.

- ÖZGÜVEN, Ali (1997), "İktisat Bilimine Giriş", Filiz Kitapevi, İstanbul.

- ÖZPINAR, Şansel, Öznur Demir ve Sabiha Keskin (2011), "Türkiye de İstihdamın Yapısının Değerlendirilmesi (2000-2010)", Sosyal ve Beşeri Bilimler Dergisi, 3(2), ss.133-142.

- PARASIZ, İlker (2008), "İktisada Giriş", Bilge Yayıncılık, İstanbul.

- PEKİN, Tevfik (1996), "Makro Ekonomi Para Gelir İstihdam", Bilge Basım, İzmir.

- PEKİN, Tevfik (2007), "Makro Ekonomi", Zeus Kitabevi, İzmir.

- SATLIGAN, Nail (2008), "Marksist İktisat El Kitabı", Yordam Yayınları, İstanbul.

- SAVAŞ Vural Fuat (1986), "Keynezyen İktisat Yıkılırken", Beta Basım Yayınevi, İstanbul. 
- SAVAŞ, Vural Fuat (1997), "İktisatın Tarihi", Liberal Düşünce Topluluğu Yayınları, İstanbul.

- ŞAHIN, Hüseyin (1997), "İktisat İlkelerine Bakış", Ezgi Kitapevi, Bursa.

- ŞEN, Ali, "İktisadi Kalkınmada Devlet-Piyasa Nispi Rollerine İlişkin Tartışmalara "Washington Sonrası Konsensüs Son Noktayı Koydu mu?", e Dergi, ss325341.http://edergi.atauni.edu.tr/index.php/SBED/article/viewFile/234/229. (20.04.2013).

- TATAR, Mehmet (2006), "Türkiye'de İstihdam-İşsizlik ve Çözüm Önerileri: Adıyaman İli Örneği", Kahramanmaraş Sütçü İmam Üniversitesi, SBE, Yayınlanmamış Yüksek Lisans Tezi, Kahramanmaraş.

- TBMM, "Özürlü, Terör Mağduru ve Eski Hükümlü Çalıştırma Zorunluluğu Kanunu", http://www.tbmm.gov.tr/kanunlar/k4857.html.(20.03.2013)

- TEMIR, Arif , "Özürlü İstihdamı İçin Neler Yapılmalı?" http://www.radikal.com.tr/haber.php?haberno=217967 (20.03.2013)

- TÖRÜNER, Mete (2000), "Çalışma Ekonomisi", T.C Anadolu Üniversitesi Yayınları, Eskişehir.

- TÜRKBAL, Aydın (2005), "İktisada Giriş", Aktif Yayınevi, Ankara.

- $\quad$ TÜRKCAN, Banu (2007), "Türkiye'de İşsizlik Sigortası ve İşgücü Piyasasına Etkisi", Gazi Üniversitesi, SBE, Yayınlanmamış Yüksek Lisans Tezi, Ankara.

- TÜRKOĞLU, Mustafa Erhan (2011), "Türkiye'de İmalat Sanayiinde Vergi Politikalarının İstihdam Üzerindeki Etkisi", Süleyman Demirel Üniversitesi, SBE, Yayınlanmamış Yüksek Lisans Tezi, Isparta.

- ÜLGEN, Gülden (2004), "İktisat Bilimine Giriş", Der yayınevi, İstanbul.

- ÜNAY, Cafer (1996), "Makro Ekonomi", Ekin Kitabevi, Bursa.

- ÜNLÜÖNEN, Kurban ve Ahmet Tayfun (2007), "Ekonomi", Nobel Yayınları, Ankara.

- ÜNSAL, Erdal Muzaffer (2007), "Makro Ekonomi", İmaj Yayınevi, Ankara.

- ÜSTÜNEL, Besim (1990), "Makro Ekonomi", Misırlı Matbaacılık, İstanbul.

- VARÇIN, Recep (2004), "İstihdam ve İşgücü Piyasası Politikaları", Siyasal Kitapevi, Ankara.

- YILDIRIM, Kemal ve Doğan Karaman (2001), "Makro Ekonomi", Eğitim Sağlık ve Bilimsel Araştırma Çalışmaları, Vakfı Yayınları, Eskişehir.

- YÜKSEL, İhsan (Eylül 2005), "İşsizlik Olgusunun Psikolojik Boyutu: Görgül Bir Araştırma", Ankara Üniversitesi, SBF Dergisi, 60(3): ss.255-274. 